\title{
INTRODUCTION. ON THE 150th ANNIVERSARY OF THE RED CROSS: NEW ISSUES AND PERSPECTIVES IN THE HISTORY OF WAR HUMANITARIANISM
}

\author{
Jon Arrizabalaga \\ IMF-CSIC, Barcelona \\ jonarri@imf.csic.es
}

Received: 7 February 2014; Accepted: 30 April 2014.

Citation /Cómo citar este artículo: Arrizabalaga, Jon (2014), "Introduction. On the 150th anniversary of the Red Cross: new issues and perspectives in the history of war humanitarianism”, Asclepio 66 (1): p027, doi: http://dx.doi.org/10.3989/asclepio.2014.01

Copyright: (c) 2014 CSIC. This is an open-access article distributed under the terms of the Creative Commons Attribution-Non Commercial (by-nc) Spain 3.0 License.

\section{INTRODUCCIÓN. EN EL 150 ANIVERSARIO DE LA CRUZ ROJA: NUEVAS CUESTIONES Y ENFOQUES EN LA HISTORIA DEL HUMANITARISMO DE GUERRA}

The increased presence of international humanitarian actors in the last few decades has fostered a renewed interest in non-governmental organisations and their roles both now and in the past, whether this be urgent interventions for the relief of populations afflicted by disasters either natural or derived from human action -if this distinction still has any sense in the context of a "risk society" (Beck 1992)- or the defence of human rights. This circumstance has contributed to the renewal of historical studies on humanitarianism in general and, more specifically, on war humanitarianism, including the international Red Cross movement, such that a change in the direction of the historiography has taken place.

Historical attention paid to the Red Cross has been notable from the very birth of the "International Association of aid societies for the relief of the military sick and wounded in the field" (1863) and the signing of the Geneva Convention of 1864 . There are a great deal of more-or-less official histories that have profusely documented the development and activities of the Geneva Committee - the International Committee of the Red Cross (ICRC), and of different national Red Cross societies as well as biographical studies devoted to the founding fathers of the movement and to some of its earliest promoters. Yet, some of these histories written during the last three decades of the nineteenth century, and most of those written in the twentieth century, were intended to construct and nourish a genealogy of the organisation and of its actors' involvement in order to legitimise, particularly in crucial moments of its history, the deployment of its increasingly numerous and varied interventions, by justifying at once its own trajectory and vicissitudes.

However, a new wave of historical studies in the two last decades -doubtless spurred on by John F. Hutchinson's monograph (1996)- is outlining new goals in the history of this movement by framing it in the socio-political and scientific context of the nineteenth-century Industrial Revolution and of the conflicts provoked by the colonial expansion of the European powers, as well as by that of the new powers then emerging on both sides of the Pacific ocean. ${ }^{1}$ More recently, a new generation of scholars has diversified and enlarged the purpose of this research so that the history of the international movement of the Red Cross has begun to be dealt with in a more integrated way. Thus, along with the traditional concern for the history of the Geneva Committee and the most renowned national societies, new, much more atten- 
tive, research into other national societies and local committees has been undertaken. At the same time, some of these new studies have also begun to pay attention to the mutual influence and relationships between the Red Cross movement and other contemporary movements or processes, namely, pacifism, abolitionism, feminism, militarism, commercial wars, international law, and social medicine, among others.

As a result of this, most recent studies of humanitarian action in war have illuminated the existence of vaster and more varied networks of actors, who have deployed a range of humanitarian practices in multiple and diverse spaces and spheres of action. Thus, manifold interactions are being incorporated into these new analyses, namely those between distinct humanitarian actors as well as between different sectors of political and social organisations, both in the territories and areas from which war relief was dispatched and in the locations where it was implemented.

It must be also pointed out that these renewed efforts take advantage of previous studies both historical and documentary on the Red Cross and of the increased opening of institutional archives to their inquiries. But these integrated analyses have also relied for their complexity upon the enormous possibilities provided by information and communication technologies (ICTs) to gain access to the vast wealth of printed and manuscript sources the mere location and retrieval of which was so difficult until the last decade of the twentieth century. The $150^{\text {th }}$ anniversary of the international movement of the Red Cross and Red Crescent societies at the biennium 2013-2014 is a good occasion to revisit from new angles and with renewed approaches and sources some episodes of its already long history.

Perhaps, the most remarkable consequence of this historiographical change has been to avoid any teleological temptation in interpreting the history of the Red Cross. In fact, irrespective of the nature of "mission" the work of the Red Cross had for its founders and initial promoters, its history is the product -like that of any similar institution however transcendental its purposes might be- of a contingent configuration process in which different kinds of interactions play as much a determinant role as the values upon which institutional histories of the movement have traditionally placed such emphasis. In this way, the article by Guillermo Sánchez-Martínez, "Enemies by accident, neutral on the rebound: diversity and contingency at the birth of war humanitarianism, 1862-1864", opening the dossier, offers a case study which re-examines the founding period of the Red Cross, from the publication of the first edition of Henry Dunant's Un Souvenir de Solférino (Geneva, 1862), to the initial contacts (Nov 1863) made for the call to the diplomatic confer- ence of August 1864. In this article it is shown how Dunant's campaign to promote his idea -to constitute permanent societies of relief for wounded soldiers in campaign- eventually led to the convocation of an international conference; how this conference, that gathered a reduced and plurinational group of philanthropists and military physicians, many of whom were mere observers, developed its proposals without nationalistic partiality; and how it finished by sending out an appeal to the charitable and philanthropic zeal of European public opinion for the constitution of civil aid societies in order to help the armies reduce their insufficiencies in relieving their wounded.

This appeal contained an agreed model for these societies, namely that in each country a single national committee should be formed -and from which any other committee would depend- and it would offer its services to the national government in order to help its military health services in wartime. In peacetime, each national committee would devote itself to the training of voluntary nurses and build up stores of health-care material. In wartime, it could ask for help from committees of neutral countries, and give aid to its own national army, by providing voluntary nurses and establishing first-aid posts wherever the army requested. If allowed or required, it would send to the battlefield -under the military commander's ordermale nurses who were provided with the required equipment by the committee, and a white armband with a red cross for the purpose of identification. Finally, in order to coordinate collective action, these national committees could participate in international conferences and communicate with each other through the Geneva Committee.

The fact that most of those involved in sending out this appeal were just observers did not prevent them from leaving the Conference as propagandists of an already in-progress work, committed to introducing it in their native countries. In this manner, a simultaneous call spread throughout Europe to activate a new health-care technology whose practical efficacy soon became manifest, so that the 1863 Conference would remain for posterity as the origin of the movement of national societies of the Red Cross. This healthcare technology was to contribute, with no discussion about causes, ${ }^{2}$ to a remedying of the catastrophes its proponents were afraid would derive from international wars fought with newly-developed and highlydestructive armaments. ${ }^{3}$

Annexed, however, to the final resolutions of the 1863 Conference were a number of pleas to be taken into consideration by governments, namely, that aid committees were accepted and their mission made easier; that neutrality was proclaimed for their ambulances and hospitals, the official health-care person- 
nel, the voluntary nurses, the civil population who relieved the wounded, and the wounded themselves; that a single sign was adopted for the military health services of all the armies as well as a single flag for hospitals and ambulances -the same red cross on a white background to be found on the voluntary nurses' armband.

The unexpected performance of the participants at that Conference and the commitments they took upon themselves gave rise to the possibility of an international agreement to guarantee the immunity of the wounded and of the health-care equipment for their relief. This led the Conseil Fédéral Suisse to invite European governments to debate and sign a convention for this purpose. The resulting diplomatic congress, held in Geneva in August 1864, and calling upon European governments -but not sovereigns- concluded with the signature of the Convention pour l'amélioration du sort des militaires blessés en campaigne by twelve states, namely Baden, Belgium, Denmark, France, Hesse-Darmstadt, Italy, the Netherlands, Portugal, Prussia, Spain, Württemberg and Switzerland itself. In an unprecedented race to be the most humanitarian, the Congress settled nothing less than neutralisation, while there were wounded, of ambulances and hospitals and of all the personnel assigned to their care, including managers and chaplains, with the guarantee that they could stay caring these soldiers and later be accompanied back to the advance guard of their army. A number of other guarantees followed to this one. First, the equipment of a permanent hospital would pass over to an occupying army, but that of the ambulances would be exempted. Second, the armies would stimulate humanitarian behaviour in civilians by guaranteeing them treatment as neutrals if they provided health-care relief, by exempting them from lodging troops, and by reducing their war taxes if they were in charge of caring for the wounded at home. Third, wounded or sick soldiers would be cared for with no distinction of country, and those having recovered who were invalid would be returned home; and still more, the same fortune would apply to those recovered and "valid" if they promised to surrender their arms, so that all of them would be guaranteed immunity during their return home, and this could even see an immediate return of the wounded if both sides agreed it. Fourth, hospitals, ambulances and convoys of wounded would have a single flag, and the personnel an armband with a red cross on a white background. And fifth, the execution of these commitments would fall to the army commanders. The elaboration of these principles stands in moving contrast to the degrees of cruelty which were then, and are nowadays, part of modern war.

Paradoxically, by express decision of the governmental delegates, the signed Convention did not refer at all either to civil aid societies or to voluntary nurses. However, the mere announcement that this conference was to be held and the publicity surrounding the new Convention -and because it stipulated the neutrality of the wounded and their carers, and the economic cost of keeping immobilised in peacetime such a huge amount of resources was unthinkablemeant that these initiatives gradually received the corresponding governmental permissions for their implementation, though the actual level of official support fluctuated from one country to another. Some of the most reluctant governments had no choice but to accept the existence of these aid societies and to rely on their help. Indeed, because care of the wounded without distinction of country applied to the countries that had accorded to the Convention, those not having initially signed it ended up doing so as soon as they were involved in a new war. ${ }^{4}$ In sum, the Geneva Convention had emerged as a law technology for the purpose of health care in war, and its consolidation marked the beginning of Humanitarian Law. ${ }^{5}$ Moreover, this law technology was to be identified by the same banner as the one which identified the provision of health-care relief by Red Cross societies.

However, the historical evidence shows that the different national aid societies and committees that were gradually constituted throughout the subsequent years, far from complying with a single pattern and assembling as a harmonious movement with a homogeneous perspective, emerged -it could not be otherwise- greatly conditioned by the values of their respective societies. Therefore, there appeared such variable versions as the para-governmental Prussian society and the Italian "Risorgimento" committees, the failed process to induce the United States government to sign the Geneva Convention (1866-1870) and the tutelary introduction of an aid society in Egypt (1872). ${ }^{7}$ It is also obvious that, once both technologies were socially implemented, the prevailing humanitarian and scientific cultural habits led those involved in relief work in the field to develop multiple approaches to specific issues and multiple new solutions in each case. The impetus of this new health-care technology opened the door to a wider and disseminated search for technological solutions to the transportation of the wounded over long and short distances. It also fostered studies concerned with technical and sanitary improvement of premises for provisory or permanent lodging, stimulated works on prophylaxis and on hygiene and surgical procedures for amputations, and so on

In the same way, the sanction of the law technology -the novelty of a formal compromise that obliged all the signatory nations because it was placed over them- intensified attempts to redefine the "Law of Nations" (ius gentium) in the direction of arbitration 
and codification as a result of "collective rational action". In scarcely ten years, international law codifications were proposed, the Geneva Convention was modified (with no legal effect), the treaty of Washington that fixed the conditions by which an arbitration was considered valid, was signed, the Institut de Droit International and the International Law Association were founded, clauses promoting previous treaties, such as that of Paris in 1856, to this supranational level were introduced, and a conference was held in Brussels to define the Laws of War.

In the end, the official sanctioning of both technologies opened the door to new imperatives to action. For instance, once relief for the wounded on the battlefields had become a pressing concern, aid societies' internal debates over their aims, activities, organisation and means were accompanied by the rise, beyond the movement led from Geneva, of many different initiatives. This was the case, after Florence Nightingale's early rejection of the "Genevan model", for the formation of the British National Society for Aid to the Sick and Wounded in War (NAS), a voluntary society for relief in war which developed independently of the Red Cross international movement until 1905, when it became one of the major institutions involved in the foundation of the British Red Cross Society (BRCS). Rebecca Gill's article "The origins of the British Red Cross Society and the politics and practices of relief in war, 1870-1906" is devoted to this history. ${ }^{8}$ It examines the controversial origins and practices of the NAS on the occasion of its involvement in a number of armed conflicts both European (the Franco-Prussian war, the Paris Commune, the Carlist war, the TurkoSerbian war) and colonial (the South African war) during the last third of the $19^{\text {th }}$ and first years of the $20^{\text {th }}$ centuries. Particular attention is paid to the specificities of the NAS' history -and more generally, to the foundation of the BRCS-, particularly the concerns and aims of their founding members, their close links to the Order of Saint John of Jerusalem and the British army, their disregard of the Geneva Committee, and their contribution to the development of first aid as a new medical specialty in both war and civil society. Last but not least, it is noted how important the biographies of some of these actors, such as John Furley (1836-1919), are to a better understanding of the history of humanitarianism. In the end, the NAS' history shows that the international movement of the Red Cross was by no means the only institutionalisation of modern war humanitarianism in late nineteenthcentury Europe, but just the most successful.

Early debates about the NAS are also one of many examples available of the differences between what aid societies believed they were promoting, what the governments thought they were approving in subscribing to the Geneva Convention, and what public opinion made of all this. ${ }^{9}$ In fact, the variety of ambulances -both mobile and permanent- sent from diverse countries and committees, by actors of the most varied ideological views, to relieve the wounded in the Franco-Prussian war, as well as their disparate actions on the occasion of the siege during La Commune, made obvious that, once the precise terms of the articles of the Geneva Convention (1864) and of the resolutions of the Conference held one year before had been forgotten, there was a widespread social reading that humanitarian volunteers had the right to intervene on the battlefield to relieve the wounded. Moreover, it was widely assumed that this right was legally enshrined in the obligation of the armies at war to respect, and to protect, the wounded and their carers. The history exposing in parallel the humanitarian operations of all these ambulances and the highly notable discrepancy between their intentions and values is still to be written. The discrepancies between Thomas Longmore and Loyd Lindsay at the NAS -exposed by Gill- illustrate some of these facets.

These manifold discrepancies provoked a generalised reaction by the military commanders -both of the executive and of the health services- to uphold the fact that voluntary nurses were not mentioned at the Geneva Convention, and the subsequent decision, taken in the Congrès international sur le service médical des armées en campagne held in Paris in 1878, that voluntary ambulances on the battlefield were from now on forbidden. Scarcely fifteen years after this door had been opened, the range of socially generated possibilities pertaining to the granting of aid to the wounded in the field was reduced to the option of accompanying national armies in their campaigns. And from the 1890s these campaigns would take place on the occasion of conflicts in the European colonies.

However, the events of this period have become part of a "lost decade" attendant upon the absence of specific studies concerning the 1880 s -roughly speaking-, a period to which general histories of the Red Cross have also paid little attention except by referring to the revival of international conferences on the occasion of the twentieth anniversary of the movement and to the birth of the American Red Cross. There are multiple factors contributing to this omission. Among them there is the fact that this period was propitious neither for elegy nor for the epic genre because of the absence of wars in Europe. The fading of the narrative of heroism, abnegation, philanthropy and charity which had been to some extent the basis of aid societies' appeal, meant that many of them undertook a series of more-or-less convincing and unfocused refoundations. ${ }^{10}$

Traditional histories have usually followed suit by agreeing that, in the absence of war, aid societies' 
low profile was the correct one. Yet, this issue should be tackled not only because the past cannot be dealt with as a history of achievement, but also because it is necessary to account for the involvement of the Red Cross movement in a period in which international relationships were reshaped, and there arose to prominence those who advocated a military doctrine which claimed that the best way to make war was to minimise suffering by fighting it in the most rapid and implacable way -those "philanthropists in their own way" as stated by Gustave Moynier. ${ }^{11}$ The aid societies themselves also contributed to the "lost years" of this period for they were unable to establish a common cause consistent enough to remain active and coordinated in peacetime.

Indeed, although the international movement of the Red Cross did not officially begin to expand its repertoire of action in circumstances beyond its founding aims until after the First World War, debates on whether it was appropriate to undertake humanitarian interventions in the face of other disasters as well as other forms of conflict (uprisings, civil and colonial wars) accompanied it from the beginning. As exposed by Jon Arrizabalaga and Guillermo SánchezMartínez, in the third of the articles gathered in this dossier -"Humanitarian aid in peacetime: conflicting narratives in the international Red Cross movement, 1867-1884" - the recurrent debate concerning aid in peacetime combined two entirely different discussions, namely what preparations should be undertaken in order to be ready in case of war, and whether aid societies ought also to be devoted to any useful activity beyond these preparations, specifically in the face of peacetime disasters of every kind -including epidemics, fires, floods, droughts, famines, and mining or railway accidents. This debate -driven from outside as well as inside the aid movement- and in which the Geneva Committee was always reluctant to engage, reached its apogee at the second international Conference of aid societies for relief of wounded soldiers held at Berlin in 1869, in the middle of the political process of German unification under the aegis of Prussia. The outbreak of the Franco-Prussian war (1870-1871) diverted aid societies' attention away from these discussions to more pressing priorities and, when the debate was resumed after the war, it was strongly conditioned by the authority of the victorious Prussian army by virtue of the efficacy of its model. This authority was also transferred to the organisation of armies all around the world, including countries as far away from Europe as Japan and Chile. Yet, further debate was also conditioned by the development of new actors and new initiatives in public "hygiene" in Europe. From the subsequent debates and the contemporary humanitarian practices in peacetime undertaken by different national Red Cross societies before the third international conference of aid societies held in Geneva in 1884, it is clear that they gradually converged with contemporary movements concerned with the search for social protection for the victims of modern industrial hazards; and, again, that each national aid society adjusted their peacetime activities in a varied way, according to the peculiar circumstances and values of their particular country, although these activities were always supplementary to their own raison d'être -that of caring for the soldiers wounded in campaign.

From what has been said so far, it may be assumed that during the 1890s aid societies' foundational raison d'être began to coexist with -and sometimes fuelled- two emerging features, namely an increasing militarism that would lead to the revision of the Geneva Convention at The Hague (1898) as well as to the massacre of the First World War -a line not dealt with in this dossier- and growing pressure to intervene not only in international wars, but in the powers' expansionist endeavours to conquest, colonise, and hold territories all around the world. In this way, war, empire, science and progress became the interlocking forces that conditioned the rise of war humanitarianism. The practical translation of the unsolved debate over national Red Cross societies' role in peacetime and the extent to which it was a response to military needs in the colonies of the imperial powers is one of the less studied aspects in the history of the Red Cross. This is the subject of Leo van Bergen's article, 'On 'war task' and 'peace work': The Dutch East Indies Red Cross between colonial wars and the Second World War".

Van Bergen focuses on the activities of the Dutch East Indies Red Cross (DEIRC) in the period between the end of the Aceh colonial wars (1873-1907) and the beginning of the Second World War, as well as on the debates over the peacetime role of the Dutch Red Cross (DRC) in the Dutch colony that in 1945 became modern Indonesia. As Van Bergen demonstrates, after having operated in the Aceh colonial wars in the service of the Dutch army, the DEIRC became more autonomous after 1922 when it entered the League of Red Cross Societies -founded in Paris in 1919 with the mission of coordinating relief assistance in emergency circumstances beyond warlike conflicts, mostly natural disasters and epidemics. The DEIRC's most important peacetime activities during the 1920s and 1930s were focused on preparations in case of war-Japanese expansionism having been perceived as the main threat and Japan's armed invasion of Manchuria in 1931 having become the trigger of a serious alarm- even when the Red Cross propaganda made great effort to hide this in order to win the civil population's sympathy in the face of radical pacifists. During the 1920s it began to develop new peacetime activities such as social work in policlinics (mainly in the bigger cities like 
Batavia [Yakarta] and Buitenzorg [Bogor]) and financial support to other Red Cross organisations (soon interrupted as a result of the economic crisis). Yet, the DEIRC flourished most in the 1930s, despite the fact that its peacetime activities gradually moved throughout this decade to preparations for war. Last but not least, the DEIRC's mobilisation was burdened by the prevailing European imaginary of the Red Cross movement, one which fuelled a fatalist image of the natives whose "Eastern character" allegedly prevented them from getting involved in practical tasks, as well as by a lack of commitment amongst European residents in the Dutch East Indies, who were deemed deficient in "a character of national or local patriotism".

To some extent, the situation described by Van Bergen arose from the fact that, increasingly, European war humanitarianism required a previous declaration of a "state of war" for its right of intervention. This in turn rested upon an elucidation of whether the contenders fitted the conditions for being declared belligerents. War was recognised as such only when the sides recognised this condition in each other or when judged accordingly by the European powers. This explains the absence of the aid societies' international involvement in civil and colonial wars. Moreover, this was reinforced by the fact that the international movement only recognised one society per nation and only included those nations deemed sufficiently "civilised". Until well after the Second World War, this conditioned the prevailing view of conflicts in the colonies whereby the belligerent status of the insurgents was not recognised and non-intervention was justified in wars against "barbarian peoples". As John Stuart Mill had once proclaimed:

\footnotetext{
"There is a great difference (for example) between the case in which the nations concerned are of the same, or something like the same, degree of civilization, and that in which one of the parties to the situation is of a high, and the other of a very low, grade of social improvement. To suppose that the same international customs, and the same rules of international morality, can obtain between one civilized nation and another, and between civilized nations and barbarians, is a grave error, and one which no statesman can fall into, however it may be with those who, from a safe and unresponsible position, criticise statesmen. Among many reasons why the same rules cannot be applicable to situations so different, the two following are among the most important. In the first place, the rules of ordinary international morality imply reciprocity. But barbarians will not reciprocate. They cannot be depended on for observing any rules. Their minds are not capable of so great an effort, nor their will sufficiently under the influence of distant motives. In the next place, nations which are still barbarous have not got beyond the period during which it is likely to be for their benefit that
}

they should be conquered and held in subjection by foreigners. Independence and nationality, so essential to the due growth and development of a people further advanced in improvement, are generally impediments to theirs. The sacred duties which civilized nations owe to the independence and nationality of each other, are not binding towards those to whom nationality and independence are either a certain evil, or at best a questionable good."12

War humanitarianism and its relationship with race, empire and understandings of civilisation are also examined in the final contribution to this dossier. This article analyses the kind of problems faced by a political regime governing a territory where its authority was being both disputed internally and externally and where its protectorate wanted to establish its own aid society. In this case, where an insurgency set itself up as an entity defending a self-proclaimed sovereignty, what chance had it to found an aid society that was recognised by the international Red Cross movement? Remarkably, Francisco Javier MartínezAntonio's article -“Resilient modernisation: the Red Cross and Moroccan Agency from Hassan I to the Rif Republic, 1886-1926"- shows the room for dispute that existed over moral autonomy and the right to sovereignty depending on the degree of civilisation. Specifically, he analyses how the Red Cross international movement in Geneva received the claims by the Riffian leader Abdelkrim to establish a Red Cross/ Crescent society in the self-proclaimed Republic of Rif as well as the paradoxical distance between the efforts to exercise a colonial humanitarianism by the Spanish and French Red Cross societies, and the Riffian endeavour also to be accepted in the concert of "civilised" nations by means of a compromise with war humanitarianism.

\section{$* * *$}

This dossier has its origins in the international seminar "War, humanitarianism, progress, homeland, colonies ...: Vicissitudes in the movement of Red Cross societies between 1863 and 1927", held in the Residència d'Investigadors (CSIC-Generalitat de Catalunya) at Barcelona in June 2013 under the auspices of the research project "Sanidad militar, medicina de guerra y humanitarismo en la España del siglo XIX" (HAR2011-24134), funded by the Spanish Government. I would like to thank its contributors for their participation as well as for having made possible with their support and encouragement the completion of this special edition. I am especially indebted to Guillermo Sánchez-Martínez and Rebecca Gill for their inestimable help in preparing this introduction. Last but not least, our thanks to Anne-Louise Oakes for her most valuable linguistic assistance. 


\section{NOTES}

1 Van Bergen (1994, 2004), Moorehead (1999), Taithe (1999), Bennett (2005), Forsythe (2005), Festa (2010), Barnett (2011), Eckart (2011), Gill (2013), and Lathion (2013), among others.

2 "It has been urged that instead of seeking for expedients whereby war may be rendered less terrible, it would be preferable to attack the evil at its root, and labour to promote the universal and permanent pacification of the world. Our opponents, by their arguments, would seem to insinuate that our efforts have no higher aim than to legalise war, by making it appear as a necessary evil. Is this criticism seriously made? I cannot believe it. Most assuredly we desire as much as any one can that men should cease to slay each other, and repudiate this relic of barbarism which they have inherited from their fathers; with the aid of Christianity, this result will sooner or later be attained, and we applaud the efforts of those who are striving for the softening of manners. Yet, in our opinion it will be necessary still for longtime to count on human passions and to suffer their deadly effects. Therefore, if all they cannot be entirely and immediately prevented, why do we not to try to reduce them? Charity asks us for it, and that is because we have heard his voice that we are here" (Gustave Moynier in CIARC, 1863, p. 8).

3 As suggested by one participant at this conference, the development of armament technology was already perceived at the time as fuelling a "reckless tendency, a strange optimism that leads us to believe that these means with which we expect to completely floor the enemy, will not have any action on us" (Nicasio Landa in CIARC, 1863, p. 41).

4 Austria, for instance, after having first rejected the call to strengthen its aid societies and considering it unnecessary to subscribe to the Geneva Convention by stating that its military health services and means for transferring the wounded were sufficient, eventually signed it on 21 July 1866 as soon as it began to lose the war with Prussia. The same had occurred in previous weeks, as a result of the outbreak of the war, by the states supporting Austria, namely Bavaria and Württemberg -whose signature was still to be ratified-as well as Russia. And the Papal States, which were reluctant to accept any declaration close to recognising man's rights, adhered to the Geneva Convention in 1867 , when their military resistance to Italian unification was being defeated.

5 A preliminary analysis of the Red Cross model as based upon two technologies, namely one health-care technology and another law technology was offered at the paper by Guillermo Sánchez-Martínez, Jon Arrizabalaga and J. Carlos García Reyes, "Red Cross' first design and its displacements in the Spanish civil wars of the 1870s", presented in the Annual Meeting of the Society for Social Studies of Science, held at Copenhagen on 17-20 October 2012.

6 "The American Association for the Relief of the Misery of Battle Fields", promoted by Henry W. Bellows, Elisha Harris and Theodore Roosevelt Sr., among others, had this as its specific aim.

7 This issue has not been specifically studied so far.

8 This is developed further in Gill (2013).

9 See Sánchez Martínez (et al., 2014).

10 On the French case, see Chrastil (2008).

11 Moynier (1882), p. 230 ; “Le plus grand bienfait à la guerre est la fin rapide de la guerre. Il faut pouvoir disposer, à cet effet, de tous les moyens qui ne sont pas absolument abominables". Letter by General Von Moltke to the lawyer J. C. Bluntschli, 11 December 1880. See Revue de droit international et de législation comparée, 13 (1881), p. 81.

12 Mill (1859), p. 772.

\section{BIBLIOGRAPHY}

Barnett, Michael (2011) The Empire of Humanity: A History of Humanitarianism, Ithaca (NY), Cornell University Press.

Beck, Ulrich (1992) Risk Society: Towards a New modernity, London, Sage.

Bennett, Angela (2005) The Geneva Convention. The Hidden Origins of the Red Cross, Stroud (UK), Sutton.

Van Bergen, Leo (1994) De Zwaargewonden Eerst? Het Nederlandsche Roode Kruis en het vraagstuk van oorlog en vrede 18671945, Rotterdam, Erasmus Publishing.

Van Bergen, Leo (2004) Een Menslievende en Nationale Taak. Oorlog, kolonialisme en het rode Kruis in Nederlandsch-Indië, Soesterberg, Aspekt.
[CIACR, 1863] Conférence internationale pour examiner les moyens de pourvoir a l'insuffisance du service sanitaire dans les armées en campagne, Genève, Imp. Ramboz et Schuchardt.

Chrastil, Rachel (2008) “The French Red Cross, War Readiness, and Civil Society, 1866-1914”, French Historical Studies, 31, (3), pp. 445-476.

Eckart, Wolfgang (2011, and Phillip Osten), eds., Schlachtschrecken, Konventionen. Das Rote Kreuz und die Erfindung der Menschlichkeit im Kriege, Freiburg, Centaurus Verlag.

Festa, Lynn (2010) "Humanity without Feathers", Humanity 1 (1), pp. 3-27.

Forsythe, David P. (2005) The Humanitarians: The International Committee of the Red Cross, New York, Cambridge University Press. 
Gill, Rebecca (2013) Calculating Compassion: Humanity and Relief in War, Britain 1870-1914, Manchester, Manchester University Press.

Hutchinson, John (1996) Champions of Charity: War and the Rise of the Red Cross, Boulder (Co), WestView Press.

Lathion, Valérie (2103, and Roger Durand), eds., Humanitaire \& Médecine.1. Les premiers pas de la Croix-Rouge 1854-1870, Geneva, Genève Humanitaire, Centre de Recherches Historiques - Institut d'Histoire de la Médecine et de la Santé

Mill, John Stuart (1859) "A Few Words on Non-Intervention", Fraser's Magazine, 60, (360), p. 772.

Moorehead, Caroline (1999) Dunant's Dream. War, Switzerland and the History of the Red Cross, London, Harper Collins.
Moynier, Gustave (1882) La Croix-Rouge: son passé, son avenir, Paris, Sandoz-Thuillier.

Sánchez Martínez, Guillermo (2014 [forthcoming], and Jon Arrizabalaga) "Transforming the meaning of war medicine and challenging Red Cross' earliest humanitarian agenda: the civil wars in Spain, 1870-1876". In : Valérie Lathion and Roger Durand (eds.), Humanitaire \& Médecine. 2. La Croix-Rouge à l'épreuve du feu, 1870-1914, Genève, Genève Humanitaire, Centre de Recherches Historiques - Institut d'Histoire de la Médecine et de la Santé.

Taithe, Bertrand (1999), Defeated Flesh: Welfare, Warfare and the Making of Modern France, Manchester, Manchester University Press. 